\title{
Dampak Covid-19 Terhadap Implementasi Pembelajaran Daring Di Sekolah Dasar
}

\author{
Syaifullah$^{1}$, Nur Syariful Amin', Nikman Azmin ${ }^{3}$, Muh Nasir $^{4 *}$, Bakhtiar $^{5}$ \\ ${ }^{12345}$ Dosen Sekolah Tinggi Keguruan dan Ilmu Pendidikan (STKIP) Bima \\ Email: muh.nasir_bio@stkipbima.ac.id ${ }^{4 *}$
}

\begin{abstract}
Abstrak
Tujuan penelitian ini adalah untuk mengaanalisis dampak terhadap proses pembelajaran dan kesiapan guru Sekolah Dasar (SD) Dalam menghadapi pembelajaran daring masa pandemi covid-19. Subjek penelitian 75 orang guru Sekolah Dasar di Kota Bima, Nusa Tenggara Barat. Jenis penelitian yang digunakan deskriptif kualitatif, dengan teknik pengumpulan data angket dan wawancara. Dalam penelitian ini, pengumpulan data diperoleh dari berita dan artikelartikel pada jurnal online. Peneliti melakukan penelusuran artikel dengan menggunakan kata kunci Dampak Covid-19 dan Pembelajaran Daring. Teknik penelitian yang dilakukan dengan dokumentasi, yaitu mencari data mengenai hal-hal atau variabel yang berupa catatan, buku, makalah atau artikel, jurnal dan berita. Dalam uji validitas peneliti menggunakan triangulasi sumber data. Hasil penelitian menunjukkan bahwa terdapat beberapa kendala yang dialami oleh murid, guru dan orang tua dalam kegiatan belajar mengajar online yaitu penguasaan teknologi masih kurang; penambahan biaya kuota internet; adanya pekerjaan tambahan bagi orang tua dalam mendampingi anak belajar; komunikasi dan sosialisasi antar siswa, guru dan orang tua menjadi berkurang; dan jam kerja yang menjadi tidak terbatas bagi guru karena harus berkomunikasi dan berkoordinasi dengan orang tua, guru lain, dan kepala sekolah.
\end{abstract}

Kata Kunci: Dampak COVID, Implementasi Pembelajaran Daring.

\section{PENDAHULUAN}

Wabah corona virus disease 2019 (Covid-19) yang telah melanda 215 negara di dunia, memberikan tantangan tersendiri bagi lembaga pendidikan. Untuk melawan Covid-19 Pemerintah telah melarang untuk berkerumun, pembatasan sosial (social distancing) dan menjaga jarak fisik (physical distancing), memakai masker dan selalu cuci tangan. Melalui Kementerian Pendidikan dan Kebudayaan, Pemerintah telah melarang semua aktivitas sekolah maupun perguruan tinggi untuk melaksanakan tatap muka dan memerintahkan untuk menyelenggarakan pembelajaran secara daring (Surat Edaran Kemendikbud Dikti No. 1 tahun 2020 (Firman dan Rahayu, 2020). Pandemi COVID-19 membawa pengaruh besar kepada semua lintas kehidupan, khusunya pendidikan. Akibat dari pandemic COVID-19, pelaksanaan sekolah dari taman kanak-kanak hingga universitas di tutup. UNESCO mengatakan bahwa ada 300 juta murid terganggu kegiatan sekolahnya dan penutupan sekolah sementara akibat dari kesehatan dan krisis (Herliandry, 2020).

Ribuan sekolah di Indonesia menutup sekolah sebagai upaya untuk menghentikan penyebaran Covid-19 (Arifa, 2020). Tanggapan Unesco sebagai lembaga yang bergerak di bidang pendidikan, sangat menyetujui pelaksanaan pembelajaran dengan menggunakan wadah daring atau upaya pembelajaran jarak jauh, sehingga pembelajaran dapat dijangkau oleh murid dimana pun berada. Pengaplikasian pembelajaran daring ini adalah bukti dari revolusi industry 4.0, dimana pengaksesan teknologi tidak terbatas, sehingga memungkinkan pelaksanaan pembelajaran daring atau jarak jauh (Verawardina dan Jama, 2018). Pembelajaran daring memiliki manfaat seperti membangun komunikasi serta diskusi antara guru dengan anak, anak saling interaksi dan berdiskusi dengan satu dan lainnya, memudahkan anak berinteraksi dengan guru dan orang tua, sarana yang tepat untuk melihat perkembangan anak melalui laporan orang tua dengan tujuan orang tua dapat melihat langsung perkembangannya, guru dapat dengan mudah memberikan materi kepada anak berupa gambar, video, dan audio yang dapat diunduh oleh orang tua langsung, dan mempermudah guru membuat materi dimana saja dan kapan saja (Sobron et al., 2019). Agar pembelajaran daring dapat berjalan dengan efektif, diperlukakan persiapan oleh pihak sekolah dan orangtua wali murid. Pihak sekolah memberikan fasilitas kepada guru berupa perangkat laptop atau hanphone kepada Guru dan paket internet yang diperlukan. 
Sedangkan pihak orangtua mempersiapkan perangkat handphone dan paket internet serta pendampingan terhadap putra putrinya.

Berdasarkan hasil wawancara dan diskusi dengan wali murid (orang tua siswa) dan guru pengajar mata pelajaran bahwa selama ini proses pembelajaran daring jarang memanfaatkan teknologi yang telah dimiliki baik oleh sekolah ataupun siswa. Padahal media belajar merupakan bagian yang penting dalam menyukseskan pembelajaran Daring. Hal ini disebabkan karena hampir semua guru dan siswa kurang memahami teknologi, sehingga menghambat proses pembelajaran daring yang dilaksanakan, hal ini akan memberikan dampak pada keberlangsugan proses pembelajaran di Sekolah Dasar yang ada di Kota Bima. Dengan kondisi tersebut diatas, proses pembelajaran pada jenjang pendidikan anak usia dini haruslah tetap berlangsung, bahkan perhatian kepada mereka diberikan lebih dari kondisi normal. Apalagi pada anak yang orang tuanya menjadi garda terdepan penangan Covid-19. Anak memerlukan pendidikan untuk mengoptimalkan seluruh aspek perkembangannya demi masa depan dalam menempuh jenjang berikutnya.

\section{METODE}

Dalam penelitian ini, pengumpulan data diperoleh dari berita dan artikel-artikel pada jurnal online. Peneliti melakukan penelusuran artikel dengan menggunakan kata kunci Dampak Covid-19 dan Pembelajaran Daring. Teknik penelitian yang dilakukan dengan dokumentasi, yaitu mencari data mengenai halhal atau variabel yang berupa catatan, buku, makalah atau artikel, jurnal dan berita. Dalam uji validitas peneliti menggunakan triangulasi sumber data.

\section{HASIL DAN PEMBAHASAN Dampak Pembelajaran Daring}

Berdasarkan hasil wawancara terhadap responden menunjukan dengan mewabahnya pandemi Covid-19 mengakibatkan kegiatan belajar mengajar di sekolah kini harus berubah menjadi belajar di rumah secara daring atau online, dimana pelaksanaannya disesuaikan dengan kemampuan masing-maisng sekolah. Belajar daring (online) dapat menggunakan teknologi digital seperti google classroom, rumah belajar, zoom, video converence, telepon atau live chat dan lainnya. Namun pembelajaran daring bukan tidak ada masalah, banyak varian masalah yang menghambat terlaksananya efektivitas pembelajaran dengan metode daring, yaitu diantaranya adalah:

\section{Keterbatasan Penguasaan Teknologi Oleh Siswa}

Siswa sekolah dasar yang kehidupaannya masih sebatas bermain, pengetahuannya pun mungkin masih terbatas pada apa yan diajarkan oleh guru, sehingga pemahaman akan teknologi digital pendukung pembelajaran oleh sebagian besar siswa sekolah dasar masih amat sangat rendah.

\section{Sarana Prasarana Yang Belum Memadai}

Perangkat pendukung teknologi yang mahal serta kondisi ekonomi yang sedang sulit ditambah kondisi pandemi, mengakibatkan siswa serba terbatas dalam menikmati sarana dan prasarana teknologi informasi yang sangat diperlukan dengan musibah Covid-19 ini.

\section{Akses Internet Yang Terbatas}

Jaringan internet yang belum merata di setiap daerah menyebabkan ketidak mampuan siswa mendapatkan pendidikan yang merata hingga pelosok negeri mengakibatkan terhambatnya pelaksanaan pembelajaran daring

\section{Kurang Siapnya Penyediaan Anggaran}

Biaya juga turut menghambat pelaksanaan pembelajaran daring, terutama pada siswa dengan kesejahteraan yang rendah. Ketika siswa menggunakan kuota internet untuk memenuhi kebutuhan media daring, maka jelas mereka kesulitan untuk membayarnya. Ada dilema dalam pemanfaatan media daring, ketika menteri pendidikan memberikan semangat produktivitas harus melaju, namun disisi lain kecakapan dan kemampuan finansial siswa belum melaju ke arah yang sama. Negara juga belum hadir secara menyeluruh dalam memfasilitasi kebutuhan biaya untuk menunjang pembelajaran daring

Menurut (Dian dkk, 2020) mengatakan bahwa belum adanya sistem yang baku yang 
menjadi pegangan sistem pembelajaran jarak jauh menyebabkan semakin sulitnya tercapainya tujuan pembelajaran, dimana dikarenakan keterbatasan media pula mengakibatkan sistem pembelajaran secara daring cenderung hanya sebatas pemberian tugas disertai dengan dokumentasi. Hal ini tentunya mengakibatkan pengetahuan yang harusnya diperoleh siswa menjadi tidak tersampaikan, dimana siswa hanya mengerjakan tugas tanpa pemberian stimulus materi pembelajaran terkait, adanya masa pandemi ini menjadikan perubahan besar dalam tatanan dan sistem pendidikan di berbagai daerah (Agus dkk, 2020). Berbagai pihak yang terlibat dalam dunia pendidikan dapat ikut merasakan dampak yang diakibatkan oleh pandemi, mulai dari penyelenggara pendidikan, guru, siswa, hingga orangtua. Penyelenggara pendidikan, dalam hal ini sekolah harus merubah sistem pembelajaran tatap muka menjadi pembelajaran secara daring. Sekolah juga harus menyediakan berbagai alternatif proses pembelajaran bagi siswa yang memiliki keterbatasan untuk mengikuti pembelajaran secara daring. Berkurangnya kegiatan tatap muka menjadikan tugas-tugas administrasi, supervisi, dan tugas lainnya dilaksanakan secara daring dari rumah. Dampak yang lain juga dirasakan guru setelah adanya perubahan pembelajaran menjadi sistem pembelajaran daring. Guru dituntut lebih kreatif dan inovatif dalam memanfaatkan media yang digunakan selama kegiatan pembelajaran daring. Berbagai keterbatasan kemampuan guru dalam bidang IT menjadikan guru harus memutar otak dan kembali belajar mengenai perkembangan teknologi dan informasi guna mendukung proses pembelajaran daring (Setyorini, 2020). Guru harus memastikan bahwa siswa dapat menyerap pelajaran dengan baik walaupun tidak selalu berhasil maksimal seperti ketika pembelajaran tatap muka di sekolah.

\section{KESIMPULAN}

Berdasarkan hasil penelitian menunjukkan bahwa terdapat beberapa kendala yang dialami oleh murid, guru dan orang tua dalam kegiatan belajar mengajar online yaitu penguasaan teknologi masih kurang; penambahan biaya kuota internet; adanya pekerjaan tambahan bagi orang tua dalam mendampingi anak belajar; komunikasi dan sosialisasi antar siswa, guru dan orang tua menjadi berkurang; dan jam kerja yang menjadi tidak terbatas bagi guru karena harus berkomunikasi dan berkoordinasi dengan orang tua, guru lain, dan kepala sekolah.

\section{SARAN}

Adapun saran-saran yang dapat dikemukakan oleh peneliti dari hasil penelitian ini adalah sebagai berikut:

1. Pemanfaatan aplikasi pembelajaran during dengan penggunaan fitur yang ada sangat membantu dalam proses pembelajaran, tetapi pelaksanaan ini kurang efektif karena tidak semua materi yang disampaikan dipahami dengan baik.

2. Perlu adanya peningkatan kompetensi guru mengenai penggunaan aplikasi pembelajaran during, sehingga kesiapan kegiatan pembelajaran dengan menggunakan teknologi seperti saat ini dapat lebih dimaksimalkan.

\section{UCAPAN TERIMA KASIH}

Ucapan terima kasih kami sampaikan pada kemenristikdikti/kemendikbud RI yang telah mendanai penelitian ini sampai selesai dan semua pihak yang telah membantu dalam pelaksanaan penelitian ini.

\section{DAFTAR PUSTAKA}

Agus Purwanto, Masduki Asbari, dkk. 2020. Studi Eksploratif Dampak Pandemi Covid-19 Terhadap Proses Pembelajaran Online di Sekolah Dasar. Edu Psy Couns Journal. Volume 2, Nomor 1

Arifa, F. N. 2020. Tantangan pelaksanaan kebijakan belajar dari rumah dalam masa darurat COVID-19. Bidang Kesejahteraan Sosial Kajian Singkat Terhadap Isu Aktual Dan Strategi, 12 (1), 1-7

Azmin, N., \& Nasir, M. (2019). Penerapan Model Pembelajaran 5E Untuk Meningkatkan Keterampilan Proses Sains Dan Sikap Ilmiah Siswa Kelas 
VIII SMP NEGRI 6 KOTA

Bima. ORYZA (Jurnal Pendidikan

Biologi), 8(2), 40-46.

Dian Ratu, Hascaryo, Barokah. 2020. Pendidikan Dalam Masa Pandemi Covid-19. Jurnal Sinestesia, Vol. 10, No. 1

Firman, F., \& Rahayu, S. 2020. Pembelajaran Online di Tengah Pandemi Covid-19 Indonesian Journal of Educational Science (IJES), 2 (2), 81-89

Herliandry, L. D., Nurhasanah., Suban, M. E., \& Kuswanto, H. 2020. Pembelajaran pada masa pandemi COVID-19. Jurnal Teknologi Pendidikan, 22 (1), 65-70

Setyorini, I. 2020. Pandemi Covid-19 dan Online Learning: Apakah Berpengaruh Terhadap Proses Pembelajaran Pada Kurikulum 2013. Journal of Industrial Engineering \& Management Research, 1(1), 2020, 95-102

Sobron, A. ., Bayu, Rani, \& Meidawati. 2019. Persepsi Siswa Dalam Studi Pengaruh Daring Learning Terhadap Minat BelajarIPA. Scaffolding Jurnal Pendidikan Islam Dan Multikulturalisme 2 (2), 20-29

Verawardina, U., \& Jama, J. (2018). Philosophy TVET di era derupsi revolusi industri 4.0 di Indonesia. Jurnal Filsafat Indonesia, 1 (3), 104-111. 